\title{
Contextual Restriction in Business English Translation
}

\author{
Yuanyuan Gao \\ Foreign Languages College, Qingdao University of Science and Technology, Qingdao 266061, China \\ Email: mapleyuan@126.com
}

\begin{abstract}
This paper mainly studies the contextual restriction in business English translation from the perspectives of linguistic context, situational context and cultural context respectively. To avoid mistranslation resulting from translators' neglecting the contextual restriction, this paper also comes up with relevant suggestions for business English translation. The research aims at reminding translators of the contextual restriction in translating so as to produce correct, exact and proper translation.
\end{abstract}

Index Terms - linguistic context, situational context, cultural context, business English translation, restriction

Today countries get involved inevitably in closer interaction with each other and big companies are looking eagerly for foreign trade partners, in which process they find effective communications are fundamentally important. Business English translation facilitates greatly cross-cultural communications among companies in foreign trades. Proper translation conveys clearly the speaker's/writer's meaning and intention, while improper translation leads both parties to a difficult and dangerous situation. Contexts exert great influence on business English translation, the ignorance of which will surely result in mistranslations and great loss for both parties.

\section{Context}

The concept of context was first put forward by the anthropologist B. Malinowski (1923) and was expanded by Firth (1950) who incorporated the subjective and objective environment into the concept.

Generally speaking, context refers to the internal and external environment of the communication. The internal environment is linguistic context including the temporary or stable relationship between word and phrase, sentence and sentence. External environment refers to verbal context which involves the field of discourse; the scope of the theme of the speech; mode of discourse, the way that word activities happen or the pattern of communication; and the tenor of discourse, which refers to the relations of both sides in the communicative activities. Nowadays, it is generally believed that context includes not only the content that exists before or after a certain piece of work, but also the subjective and objective environment.

This study divides context into three categories according to their restrictive impact in business English translation: linguistic context, situational context and cultural context. Linguistic context refers to the relevant content that helps to understand a piece of information in communication, and includes the semantic relation, grammatical relation and syntactic relation. In Language and Linguistics Dictionary by R. R. K. Hartmann (1972), linguistic context is defined as the phonetics, words and phrases before or after a certain language unit. Situational context refers to the knowledge that is relevant to a certain piece of information. This kind of knowledge exists beyond text books, but is significant for understanding texts. British linguist Lyons concludes situational context as the participants, place of communication and some other factors. Cultural context refers to the related culture background. It can be divided into two aspects--custom, the mode of people's life inherited from generation to generation, and social norm, the rules and restriction obeyed by members of the society.

\section{ConteXtual Restriction in Business English Translation}

Translation involves two kinds of language--the source language and the target language. As there are no absolute synonyms between the two languages from a strict linguistic point of view, there may be meaning loss during translation. No matter how outstanding a translator is, he could not convey the exact meaning of the source language, but the approximate meaning. Translators should pay sufficient attention to the influence of context so as to avoid mistranslating.

\section{A. Linguistic Contextual Restriction in Business English Translation}

Li Yunxing once pointed out that the meaning of a word is not determined by the dictionary but by the context. The context here mainly refers to linguistic context. It is common that one word has more than one meaning in business English and which meaning to adopt is decided by what context the word lies in. Translators should not only pay attention to a particular word, but also to the other words that lie around it. For example, the word "shipment" has both meaning of "the goods that is loaded" and "the act of loading to ship". Translators should decode its exact meaning 
according to its linguistic context, as shown in the following examples.

(1) As to partial shipment, it would be to our mutual benefit if we could ship immediately whatever is ready instead of waiting for the whole shipment to be completed.

There are two "shipment"s in this sentence. The first one, along with the word "partial", constitutes a trade term to be translated as 分批装运. The second "shipment" actually refers to the goods that are loaded and is to be translated as 货 物. If translators neglect the context, they may mix up the two meanings and subject the company to profit loss. With linguistic context in consideration, the entire sentence should be translated as 至于分批装运问题, 如果我们能立即装 运目前已备好的货物，而不必等到整批货物备妥后再装运，这将对你我双方都是有利的。

(2) The order NO. 105 is so urgently required that we have to ask you to speed up shipment.

The context of this sentence is built with the subject "the order NO. 105" and the verb phrase "speed up", which determines that the "shipment" here means 装运. So, the entire sentence should be translated as 第 105 号订单所订货 物我们要急用, 请你们加快装船速度。

In business English, "floating" means 预约的 as well as 浮动的, the translation of which is also determined by the linguistic context. For example,

(1) We wish to renew our floating policy NO. 543 on the same terms as before, to cover consignments of textiles to West African ports. 我们想按原定条件将预约保险单更改为投保运至西非港口的纺织品。

Floating policy is a kind of insurance certificate similar to open policy. It is a long-term goods transport insurance contract that is signed by the insurer and the insurant on the matters of the insurance branch and claim settlement. Therefore, the "floating policy" here should be translated as 预约保单 instead of 浮动政策.

(2) The floating rate is often based on LIBOR, the rate at which banks borrow from one another. 银行的中长期货款 一般都采用浮动利率.

Regarding the linguistic context, this sentence is excerpted from an article about the bank industry. "Rate" generally means 比率, but obviously "floating rate" cannot be translated as 浮动比率. Actually in business English dictionary, "floating rate" is a professional term in the bank industry with a fixed translation version as 浮动利率.

\section{B. Situational Contextual Restriction in Business English Translation}

Business correspondences serve as the typical examples to manifest the influence of situational context. When translating Chinese business correspondences into English ones, translators should notice that English business correspondence writing has special characteristics as shown below.

(1) Dear Mr. Hamper,

I am afraid your failure to settle your account, which is overdue for more than six months, will leave us with no alternative but resort to legal proceedings.

This is to notify you that unless we receive your check for $\$ 7,550.00$ by June 30, we will place your account in the hands of our attorneys for collection.

Apparently, this business correspondence's field is to collect the payment for goods. To meet the context, six professional words are used in two sentences---account, overdue, notify, check, attorney, collection. This is one of the most outstanding features of English business correspondence.

(2) Thank you for your letter of the 16th of this month. We shall be glad to enter into business relations with your company. In compliance with your request, we are sending you, under separate cover, our latest catalogue and price list covering our export range. Payment should be made by irrevocable and confirmed letter of credit. Should you wish to place an order, please telex or fax us.

Your prompt reply would be highly appreciated.

This letter aims at establishing business relations with another company. Although it is short, polite words are frequently used in this letter to leave the recipient a good impression.

(3) You are invited to note two reasons for the price rise as follows.

In business English, "You Attitude" is frequently adopted to show the respect towards the copartner, even when the writer is expressing requirements. This feature is also decided by the business situational context.

(4) We should appreciate it if you could advance shipment.

Modal words "should" and "could" are frequently used in business letters. Besides, "should" here needn't be translated; otherwise, it would lead to mistranslation.

Moreover, a lot of common words are endowed with special meaning by business situational context.

(1) Average is of two kinds: General Average and Particular Average.

In this sentence, the word "average" means 海损 instead of 平均.

(2) We think it fair to point out that recent changes in import quotas may cause us difficulty in executing contract orders and that some delay is inevitable.

"Some" here should be translated as 稍微 instead of 一些 according to the situational context.

As business English correspondence is a kind of half-official document writing, it inevitably adopts big words to show its authority. For example, "commence" is applied instead of "begin". Some complex prepositional phrases are employed instead of single common prepositions, such as "with reference to" instead of "about", "prior to" instead of 
"before".

\section{Cultural Context Restriction in Business English Translation}

The manifestation of cultural context restriction in business English translation is mainly embodied in advertisement translation. Good advertisement translations between English and Chinese lay adequate emphasis on cultural context.

As an officially appointed ice cream supplier during the Wimbledon Tennis Championships, Haagen-Dazs carried out a brand promotion named the "The Perfect Match". Translators were facing a big challenge when thinking of its Chinese version. If this promotion were translated as 完美赛事, people would see nothing of the relation between the match and the Haagen-Dazs. Then it would be meaningless to carry out the brand promotion for Haagen-Dazs company. If the activity were translated as 绝佳搭档: 温网比赛, 哈根达斯, although it emphasized cooperative relations between the match and Haagen-Dazs, it would still make the advertisement too commercial. So, the translator had to figure out the related culture background with this commercial activity. Wimbledon Tennis Match is held in the last week in June till the beginning of July each year as the oldest and the most authorized match in tennis field. A history for as long as more than one hundred years gives birth to the unique Wimbledon Tennis Match Culture. Ice cream is one of the traditional inevitable snacks. The tennis fans will be eating ice creams while cheering for the athletes. The combination of the match, the leisure and the entertainment is exactly what the brand promotion wants to express. Taking the above into consideration, translators finally translated the "The Perfect Match" as 观温网赛事, 品哈根达斯 which not only achieved the goal of the brand promotion, but also gave Haagen-Dazs a cultural image.

Rejoice is a famous international shampoo brand. The brand name indicates that the goods will bring people joy. However, if the brand is translated as 使人高兴, people cannot figure out what relation it has with shampoo, as this translation neglects the cultural context and fails to convey exactly the embodied meaning. In Chinese, 柔顺 is used to modify nice hair, so the brand was finally translated into 飘柔. On one hand, it helps Chinese people easily know what the product is about. On the other hand, this translation doesn't deviate from the central meaning of bringing joy to people.

Chinese people always dislike the mention of death and avoid saying the words that have similar pronunciation with death. Translators should not neglect this cultural context. A famous tie brand is Goldlion. The literal translation would be 金狮 in Chinese. However, 狮 is similar to 死 in pronunciation in Chinese. Accordingly, people would feel this brand ominous and the sales volume may be influenced. So, the translation was changed into 金利来 later, which was regarded as an excellent example in advertisement translation. 金 and 利 both mean profits. 来 means come and it is the transliteration of lion. The three characters ensure the distributors a lot of economic profits.

There is a Chinese advertisement 一天一块“金星”巧克力, 令你精力充沛、生活愉悦. One English proverb "an apple a day keeps the doctor away" is well known to almost all Westerners. Therefore the translation of this Chinese advertisement smartly imitated the structure of the proverb to arouse the Westerner's interest and is translated as "A Mars a day keeps you work, rest and play."

\section{Suggestions FOR Business ENGLish TransLation}

Translators should learn more about the international trade. Simply the knowledge about English cannot ensure a good business English translator, while common sense in international trade is also indispensable. Only with the general knowledge of international trade can translators be sensitive to the words and make correct judgment among several meanings of words in business English translation.

Translators should obey the principles of faithfulness, exactness and consistency, pay sufficient attention to the context, and try to make translation equivalent to the source text. What's more, the translated version should be natural and professional.

A good translator should learn much about Western culture. Greek fables and the Bible are two main origins of Western culture, proverbs and literary quotations in English. They can be regarded as the key to the treasure house of Western culture. With good knowledge of Western culture, translators will translate exactly and properly cultural flavors of the source language into the target language.

Translators should not add extra context as they like. Once a Taiwan television retransmitted a program in which three astronauts were giving a speech before the rocket was launched. They said "we are in good shape." (我们情况良 好). The announcer of the television translated this sentence as 我们身材都很好. He also explained that the astronauts were so humorous that they even told a joke before they were sent to the international space station. The translator here made a mistake as he neglected the real context and added an extra context to that sentence according to his understanding. The same mistake may happen in business English translation.

Translators should keep strict to the context of the source language. They could add or reduce words according to the context when translating. As discussed above, a lot of polite words and modal verbs are applied in business English correspondence, and some of them needn't be translated into Chinese as they just show politeness.

Translators should pay attention to the switch between "You Attitude" and "I Attitude". Business English contains a lot "You Attitude" sentences, such as "You are invited to note two reasons for the price rise as follows". This sentence actually expresses the writer's demand although it smartly begins with the subject "You". Translators should be alert to 
this point especially when translating Chinese business correspondences into English.

A lot of deals are accomplished through business correspondences and are concluded with business contracts, so business English translation becomes particularly important. Mistranslating some words or sentences may bring both parties great economic losses. Good business English translators should have not only profound knowledge of English, but also professional knowledge about international trade. Besides, business English translators should be alert enough to the influence of context.

\section{REFERENCES}

[1] Firth, J.R. (1957). Personality and Language in Society. In Firth, J.R.(ed.) Papers in Linguistics 1934-1951. London: Oxford University.

[2] Hatim, B. (1990). Discourse and the Translation. London: Longman Group UK Limited.

[3] Hartmann R. R. K. (1972). Dictionary of Language and Linguistics (1 vols.). London: Applied Science Publishers.

[4] Li Xingyun. (2010). Description of Translation Context. Beijing: Tsinghua University Press.

[5] Malinowski, B. (1923). The Meaning of Meaning. New York \& London: Harcourt Brace Jovanovich.

[6] Nida, Eugene A. (1993). Language, Culture and Translating. Shanghai: Shanghai Foreign Language Education Press.

[7] Nida, E. A. (2001). Contexts in Translating. Shanghai: Shanghai Foreign Language Education Press.

Yuanyuan Gao was born in Tengzhou, China in 1982. She received her M.A. degree in linguistics from Dongbei University of Finance and Economics, China in 2006.

She is currently a lecturer in the School of Foreign Languages, Qingdao University of Science and Technology, Qingdao, China. Her research interests include the second language acquisition and translation. 